\title{
Environmental and Wildlife Crime in Sweden
}

\author{
Vania Ceccato \\ Associate Professor \\ School of Architecture and Environment \\ Royal Institute of Technology \\ Stockholm, Sweden \\ Adriaan Uittenbogaard \\ Research Engineer \\ School of Architecture and the Built Environment \\ Royal Institute of Technology \\ Stockholm, Sweden \\ Contact information: Vania Ceccato: vania.ceccato@abe.kth.se; +46 87908625
}

\begin{abstract}
This article discusses the nature of environmental and wildlife crime (EWC) in Sweden. A review of the international literature helps to frame the Swedish case study. The novelty of this study lies in using 11 years of police records as well as newspaper articles (Media archives) as a basis for analysis. Geographical Information System (GIS) supports the spatial analysis of EWC at municipal and coordinate levels. Since most EWCs take place outside large urban areas, this study looks closely at the cases of EWC in the rural county of Västernorrland. Findings show an increase in both EWCs recorded by the police and covered by the media in the last decade. EWC-geography varies by crime type: rural areas are in general more prone to unlawful handling of chemicals and to nature and wildlife crimes than are urban areas, where dumping and other minor EWCs are more common. Detection of EWCs is highly dependent on people's routine activities and accessibility. Drawing upon the Swedish evidence, the article closes with suggestions for improvements in research on environmental and wildlife crimes.

\section{Keywords: Environmental Damage, Environmental Crime, Green Criminology, GIS,} Media, Rural Areas, Scandinavia, Wildlife Crime
\end{abstract}




\title{
Introduction
}

Major cases of environmental and wildlife crime (EWC), like the oil spill in the Gulf of Mexico in 2010, make us reflect upon the character and impact of crimes against nature (Uhlmann, 2011). However, most EWCs happen on a much smaller scale, close to us and, as in the example below, could easily pass under-detected:

\begin{abstract}
An entrepreneur in Timra ${ }^{1}$, a municipality in Västernorrland county, northeast Sweden, was convicted of littering after he buried engines, paint cans and other hazardous chemicals on his property. His company went into bankruptcy not long after the municipal environmental authorities discovered the trash. He denied the crime but former employees confirmed the dumping. The accused entrepreneur was not convicted of environmental crime since the detailed investigation was faulty. He was instead convicted of littering and his punishment was limited to an 80-daily-fine. ${ }^{2}$
\end{abstract}

This example illustrates the difficulty for the criminal justice system to detect, register and prosecute these crimes. The police have at present a rather modest role in Sweden when it comes to detecting EWC whilst, as in the case above, the municipal environmental authorities are the most important agents in detecting and registering them. According to the Swedish National Council of Crime Prevention - BRA (2006), officials may have knowledge or suspicion that something is happening, but they lack enough evidence to make a case. It is submitted here that in order to obtain a more comprehensive view of what happens in terms of EWC (or what is missed by the system), it is necessary to investigate alternative sources of information on environmental harm. On this line of thought, this study takes advantage of data covering 11 years of police records as well as newspapers articles on EWCs in Sweden. The objective of the article is to investigate the temporal and spatial nature of environmental and wildlife crimes in Sweden. The study draws upon routine activity principles to suggest an interpretation of patterns of EWC detection. The article focuses on Västernorrland, a rural county located about a six-hour drive north of Stockholm, the capital of Sweden.

A Swedish case study is interesting for several reasons. Theory and case studies from North America and the United Kingdom dominate the international literature on crimes against nature and wildlife (e.g., Adler and Lord, 1991; Marsh, 1991; Pendleton, 1997; White, 2008). Sweden and other Scandinavian countries have a long tradition of dealing with environmental issues and being role models for other countries worldwide, which makes them an interesting case from an international perspective.

The National Environmental Protection Agency is the principal organ responsible for the environment in Sweden and faces a number of challenges. Protected areas account for eight percent of Sweden's total land area. However, forestlands are damaged each year by, for instance, pollution at the same time that factory effluents represent a threat to water and soil quality (National Encyclopaedia, 2012). There is also a need to extend the empirical evidence about EWCs in rural settings. In Sweden, although the majority of the population of 9,5 million inhabitants lives in larger cities, about a fourth live in the countryside. EWC has a 
strong rural dimension; from the total of 48 thousand police records of EWC in the last decade, 90 percent took place outside the municipalities of Stockholm, Gothenburg and Malmö, which are the largest urban areas in Sweden.

The article starts with a review of the international literature on the subject and suggests the hypotheses of study for the Swedish case. This section also includes a short discussion of how these crimes are handled by the Swedish criminal justice system, which provides the background for the analysis. Next, we frame the study area and then describe the method of study. Following this, we compare police-recorded statistics with media coverage of environmental offences from 2000 to 2011 on environmental and wildlife crime in Sweden, with a primary focus on the rural county of Västernorrland. Although not the county with many cases of environmental problems, this county was chosen because Västernorrland has had a stable representation of different types of crime (according to the Swedish penal code). The selection of this rural county was also possible because of the availability of fine-grained crime data from the police (by x,y coordinates) and national land-use databases of the area. Finally, the geography of EWC at national and county levels is discussed, drawing upon the Swedish evidence, followed by suggestions for future research.

\section{Environmental and Wildlife Crimes: Theory and Hypotheses}

EWCs can be classified according to their harm. As White (2008) noted, primary crimes are those that directly result from the destruction and degradation of the earth's resources, through human actions (e.g. deforestation or pollution of air, water, soil), while secondary crimes are those arising from the flouting of rules that seek to regulate environmental disasters (e.g. organised crimes and dumping of toxic waste). Alternatively, EWCs can be classified according to public perceptions of different types of harm. For instance, brown issues tend to be defined in terms of urban life and pollution (e.g. air quality); green issues mainly relate to wilderness areas and conservation matters (e.g. logging practices); and white issues refer to science laboratories and the impact of new technologies (e.g. genetically modified organisms). Regardless of the type of classification, EWC as an area of empirical research has been a neglected one within criminology.

One of the reasons for the neglect is that EWCs are often regarded as victimless, as they do not always produce an immediate consequence; the harm may be diffused or go undetected for a lengthy period of time. EWCs challenge the traditional views of victims as the crimes often affect groups of individuals and can involve non-conventional victims, such as non-human species, the environment and future generations. Few environmental crimes are detected because control is limited and only directed to certain geographical areas. EWC statistics are therefore underestimated, either because the crimes may go under detected for a long time or because these offences fall between the responsibilities of different authorities, for instance, criminal justice and environmental authorities (BRÅ, 2006; Skinnider, 2011). Many times, cases are dismissed because of lack of evidence that should stem from the cooperation of responsible authorities. Companies and private groups are often overrepresented among suspects and / or offenders. 
Another reason is that environmental damage may actually have been legal in the past (at least during a certain period of time) and now, although an offence, it takes place with the consent of society just because it is not regarded as a 'big problem'. The question is: why do certain activities become intolerable and are criminalised? Pendleton (1997), who looked into the criminalisation of logging in British Columbia, Canada, suggested that four socio-natural thresholds of harm were exceeded before the Canadian Forest Code was amended to include severe penalties for environmental offenses, some of which were related to rapid deforestation but also to issues of visibility, morality and unsettled conflicts between workers and companies. A relevant issue here is to find out whether criminal sanctions enforce compliance. Aimer and Goeschl (2010) confirmed the hypothesis that criminal sanctions deter environmental crimes, which supports the importance of environmental laws.

Records on harm against nature are dependent on a legal basis that sometimes conflicts with other relevant interests. This creates a lag in actions fed by a local culture of acceptance of these damaging activities, but also fed by economic interests that are equally important for the long-term social sustainability of the area. During recent decades, new environmental laws have imposed actions towards crimes against nature that go against the way natural resources have always been exploited in certain areas. For instance, municipal and county inspectors in Sweden, a crucial agent for EWC detection, declared that they experienced pressure from the municipality to not report suspected crimes, given that the municipality wants to preserve employment and entrepreneurship in the community. This is particularly true in small, rural municipalities (BRA, 2006, p. 9).

Of particular importance in this context is activism and the environmental justice movement that often put cases of EWC under the lens of the media (Aimer \& Goeschl, 2009; Sazdovska, 2009). The issues above exemplify the growing complexity and multidimensionality of this research area. As White (2003:503) suggests, criminologists needs to be able to unravel "layers of ambiguity and contestation", which often characterise cases of EWC. But how does the media cover EWC? EWCs do not often make the news as they tend to be regarded as less important. A low media interest in covering EWCs leads to public misunderstanding and ignorance of such crimes (Jarell, 2009; Marsh, 1991). Nevertheless, Sweden has seen a rise in both numbers of reports and articles, suggesting that both parties may be influencing each other into more conscious reporting. EWCs often seem to be less important as they are less tangible; neither victims nor offenders are always obvious and crimes are not always visible to the public. According to Jarell (2009), they are often put aside under the name of 'the cost of businesses'. Some cases may even be covered up or minimally reported in order to defend the local economy. When crimes show up in the media, they tend to give a distorted or partial picture of reality (Burns, 2009; Burns \& Orrick, 2002; Jarell, 2007, 2009; Lynch, Stretesky \& Hammond, 2000; Marsh 1991).

The media often focuses on the visible harm of EWCs, leaving out any background information. Marsh (1991) notes that the source is often cited as being the police, who clearly have a voice in what information comes out, and thereby regulate what is published in the media. It is also suggested that industries apply positive marketing to the media, creating a goodwill, whereby influencing public perception to cover for up for a corporate crime (Jarell, 
2009). Some would frame public opinion even before the news hits the papers. Furthermore, the media often covers a narrow time window of EWC cases, with the discovery of the crime often receiving the most attention (Burns and Orrick, 2002). Despite these limitations, media coverage is of interest for EWC research since it represents a data source independent of police records or victimization surveys.

Environmental crimes, as other types of crimes, do not happen randomly in space and time. It is suggested here that the detection, but more importantly, the location of EWCs reflect social interactions and human activities in space (Cohen \& Felson, 1979), people's spatial awareness and opportunity spaces (Brantinghamn \& Brantingham, 1984); particularly, how accessible different environments are. Lack of surveillance in remote areas should be a crucial element affecting where environmental crimes take place, such as dumping of waste. According to a Swedish public investigation (SOU, 2002), remoteness per se is not a problem; rather, it is the size of local police areas, which can vary a great deal. For example, municipalities in Southern Sweden are relatively easy for police forces to cover because of high population density, with short commuting distances between municipalities, while in the North, some of the police districts are large and often composed of more than one municipality.

\section{EWC in the Swedish Context}

In Sweden, environmental crimes are punishable by fines or imprisonment not exceeding two years, depending on whether they are carried out intentionally or negligently. For instance, a man who poured gasoline into a well in Lomma municipality in Southern Sweden was charged with serious environmental crime in July 2012. If convicted, he may stay in prison for six months to six years. According to the government penal database, serious environmental crimes refer to actions which cause or may cause serious environmental damage by pollution of air, water, soil or subsoil; storage or disposal of waste or similar substances (Regeringskansliets rättsdatabaser, 2012).

After the mid-2000s, changes in the national and European laws meant that the criminal justice system had improved possibilities to prosecute for EWC. At the national level, the strict requirement to prove that an injury or threat was caused by an EWC was alleviated; thus, more cases can reach court and be prosecuted, at least in theory. Moreover, the Coast Guard Authority has invested substantial resources towards detecting the discharge of oil, which could also lead to improved crime detection and an increase in the number of police records (BR $\AA$, 2006). However, rarely does a complaint lead to indictment and prosecution. The data from 2004 shows that out of 3,509 reported crimes, only 267 resulted in indictments, 177 reached court, and 107 reached a final judgment. Of these cases, nobody went to jail; they were suspended or resulted in fines (BRA, 2006).

What may have an impact on the nature of EWC in Sweden is what is often called "the right of public access" (Allemansrätt), the right everyone has to use others' property, land

and water, mainly by travelling across them on foot, or by residing there for a short time. This right is limited and also implies that the public must respect rights that affect one's domestic 
peace and/or economic interests. The law is violated when a person unlawfully intrudes or remains where another person has his residence (hemfridsbrott), or when a person accesses places using motorised vehicles. It is forbidden to drive vehicles on bare ground or on private roads (Swedish Environmental Protection Agency, 2011). Although hemfridsbrott is not an EWC, it indicates the uncertainties of how to interpret the right a person has to use private property as a public good, including its natural resources.

In Sweden, as in the United Kingdom (for details, see Marshall \& Johnson, 2005), some animals have been hunted for centuries. In Sweden, for example, the risk of overpopulation of certain species makes hunting not only acceptable, but also encouraged. These animals are moose, certain types of foxes, hares, rabbits, beavers, magpies and other types of birds, such as geese and crows. Although a large majority of hunters in Sweden are affiliated with the Swedish Association for Hunting and Wildlife Management, which defines hunting standards (e.g., methods, territory, weapons, proficiency and hunting season), crime against wildlife does happen. A crime against wildlife takes place when an individual infringes the limits of hunting. For example, the start and duration of the season for a particular species varies geographically; moose hunting in southern and central Sweden is allowed for two months, while in certain, small geographic areas, it is only allowed for a few days.

The processes of discovery, recording, investigation, prosecution and sentencing of EWCs are selective in Sweden, presumably as in other countries. A summary can be found in the 2006 BRA report, which indicates that fewer environmental crimes would have been detected were it not for municipal environmental inspections. The ones who first detect EWCs are the individuals who cause the damage (most often in cases of accidents), but also crucial for detection are the local environmental office, chemical inspectors, the coast guard, the public, the police, the customs service and last, the general physician. Checking for EWC is primarily performed by the supervisory authorities (mainly local environmental agencies and county governments). The police play a minor role, which essentially consists of investigating crimes that have already been discovered and recorded. Since no authority is actively looking for environmental crimes to any appreciable extent, only the most obvious and visible ones come to attention of the authorities.

The BRA report also shows that police officers do not always know what environmental crime actually is. Since inspectors have a dual role, both to be service oriented and to report crimes, not all crimes are reported, sometimes because the inspector "knows" from experience that their complaints rarely lead to prosecution. There is also a tendency for the investigation to only move forward in the cases where it is easier and less time-consuming to prove the crime. Lack of skills among those involved is also an obstacle to investigating EWC. For instance, the prosecutor has to have a good scientific background to be able to show in court the damage the offense has caused to the environment or what could have happened. EWCs that are part of organised crime or are more difficult to investigate are often rejected by the prosecutor on the grounds that the offense cannot be proved. When they are combined with other types of crimes (tax evasion or fraud), they may be redirected to other prosecutors and the "environmental" part loses its force. It has also been shown that a prosecutor's willingness to put the case forward is influenced not only by legal assessments 
and the available evidence, but also by "bad" experiences of how courts previously handled similar cases (BRA, 2006).

The motivations behind EWC vary and depend on the type of crime. There are various types of environmental crimes where the aim is economic profit; however, according to the interviews with inspectors reported by BRA (2006), EWCs are usually due to negligence. There are cases of more unscrupulous individuals who want to save money by, for example, dumping hazardous waste instead of properly disposing it, which might be expensive. Littering and dumping waste reach the news in rural municipalities and are often related to actions of local residents, not companies. Nationwide, the difference in garbage collection fees among municipalities is SEK $2500^{3}$ per year, according to the homeowner association's 2012 survey. The difference between the cheapest municipality fee and the fee paid by homeowners in the rural county of Västernorrland is about SEK 800, but the fee in Västernorrland is one-third less than the fee charged in the most expensive Swedish municipalities (Swedish Homeowners Association, 2012). Thus, it is expected that individuals living in municipalities with high fees for garbage collection would be more motivated to burn furniture and dump waste than individuals living where garbage collection is cheap.

\section{Hypotheses}

Four hypotheses guided our inquiry into the extent and pattern of environmental crime in rural Sweden.

1. Trends in EWC are expected to respond to more restrictive laws at the European level and to changes in the legal procedures at the national level, leading to higher levels of EWC detection. Police records are expected to increase after the mid-2000s as a result of these changes.

2. However, remoteness and local conditions determine levels of EWC. It is expected, for example, that individuals living in municipalities with a higher price of garbage collection would be more motivated to burn and dump waste than individuals living where garbage collection is cheaper.

3. EWC records tend to follow patterns of routine activity, awareness of space and police surveillance. This is because the detection of EWC depends on visibility and, therefore, is often associated with patterns of accessibility to places, particularly in rural environments.

4. Visibility can also takes place through the media. It is also hypothesised that more police-recorded crimes will be found in areas with greater media coverage of EWCs (in newspaper articles). 


\section{Framing Sweden and Västernorrland as a Case Study}

This study focuses on the temporal and spatial distribution of EWC by municipality, followed by a detailed analysis of the rural county of Västernorrland (Figure 1). Sweden is constituted of 290 municipalities, with populations ranging up to 800 thousand inhabitants, and averaging 31 thousand inhabitants. The size of the municipalities differs widely with an average of 1,415 square kilometers; the smallest municipality covers 8.7 square kilometers while the largest covers 19,371 square kilometers. The largest municipalities are often located in the remote, Northern areas of the country (Figure 1).

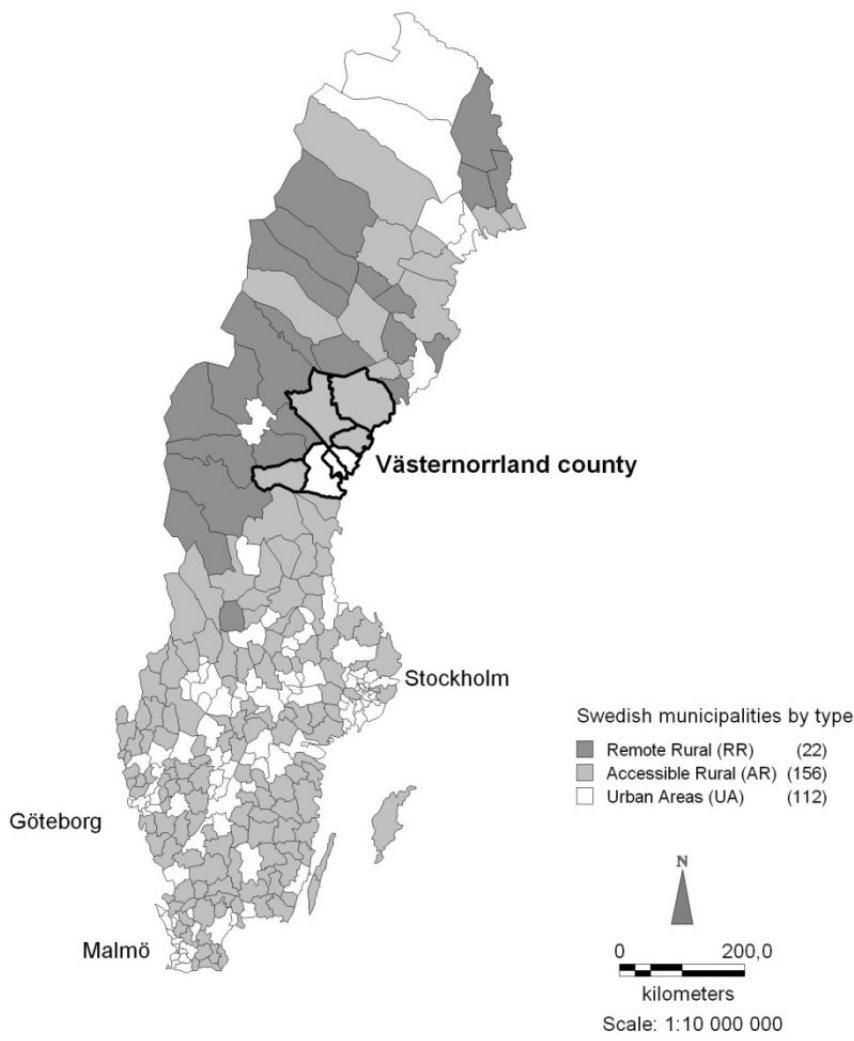

Figure 1: The Study Area - The Geographical Position of Västernorrland County in Relation to the Rest of the Country and the Swedish Capital Stockholm

The large differences between municipalities in physical, demographic and social aspects means that some form of categorization is required in order to be able to compare them. There are numerous ways to classify rural areas but, as discussed by Martin et al (2000), they are far from being unproblematic. One way is to classify municipalities by their position in the urban hierarchy, dividing them into urban and rural areas based on their population and accessibility. These criteria were suggested by the former Swedish National Rural Development Agency - SNRDA (2005) and will be adopted in this study. Remote Rural areas are more than 45 minutes by car from the nearest urban neighbourhood with more than 3000 inhabitants, whilst Accessible Rural areas are 5 to 45 minutes by car from urban 
locations with more than 3000 inhabitants. Municipalities with more than 3000 inhabitants and reachable in 5 minutes by car are regarded as Urban Areas (SNRDA, 2005).

Although crime is said to be mainly an urban phenomenon, rural areas have seen an increase in crime rates (police records) in the last decade, particularly in the Accessible Rural areas. Differences in routine activity influence the variation of crime rates in urban and rural areas together with socio-economic indicators. Looking at rates and patterns shifts of crime in Sweden, Ceccato and Dolmen (2011) suggest that despite being more dispersed, the rural population may face larger commuting distances between place of residence and workplace than their urban equivalent. This means that a share of this rural population is at higher risk of becoming a crime victim. More temporal population (e.g., tourists, visitors) and/or permanent residents in accessible rural areas indicates that they have become more targeted for property crimes than before, but also by other offences, which is indicated by an increase in seasonal public disturbance, such as criminal damage and drug-related offence. There are also regional differences in routine activity within Swedish rural areas that may be criminogenic relevant. Whilst Northern rural communities are remote, with low population density, and higher degree of isolation, Southern municipalities (although they do not constitute a homogeneous socio-economic, cultural-religious area) are strongly interconnected by influential large urban areas in Sweden (e.g., Malmoe and Gothenburg) and to the northern European continent (e.g., Denmark and Poland). Southern rural municipalities, particularly those within the urbanised triangle of Stockholm-Malmoe-Gothenburg, are therefore more exposed to local and regional flows of people and goods than the Northern rural municipalities, especially after the construction of the fixed link between Denmark and Sweden (with easier movement of goods and people, perhaps more difficult to detect illegal activities).

This study will take these findings further by investigating the distribution of EWCs, giving particular attention to Västernorrland county. The county is situated about $500 \mathrm{~km}$ north of the capital, Stockholm, and connected by national roads, air and rail. Västernorrland is composed of five municipalities with 243 thousand inhabitants total: Sundsvall has about 96 thousand inhabitants followed by Örnsköldsvik and the smaller municipalities Härnösand, Sollefteå, Kramfors, Timrå and Ånge. The county is one of least populated in Sweden and is continuously shrinking (SBC, 2011). According to the county administrative council, the region is a leading place for industry in Sweden and houses some of the top industries in wood, energy and handicrafts (Västernorrland County Council, 2012). The county offers 'a rural experience' with widespread forest areas, large rivers and the UNESCO world heritage site Höga Kusten.

\section{Method}

A detailed description of data sources used in this study is found in Appendix 1. Counts of EWC for the 290 Swedish municipalities were retrieved from the homepage of the

Swedish National Council for Crime Prevention (BRA) for the time period 2000 to 2011. The database contains all recorded offences by police, customs and prosecutors sorted by the different crime codes. For this study, crimes in the 8000-series (codes 8001-8019) have been selected as they represent all crimes against the environment and wildlife (Appendix 2). Data 
were later saved as excel files and imported into a GIS to be linked to each municipality polygon.

For Västernorrland county, $\mathrm{x}, \mathrm{y}$ coordinates for all types of EWC were gathered from the police. However, only the years 2005 to 2008 were available. The coordinates were geocoded and overlaid on a digital land-use map (GSD-maps, Sverigekartan/Fastighetskartan) of the area provided by Lantmäteriet, the land registration authority in Sweden. GIS (MapInfo 10.0) was used for converting the GSDmaps into vector files, analysing and representing the data. A buffer analysis was carried out to check the distribution of some EWCs in relation to some land-use features, for instance, roads (total number of EWCs within a $2 \mathrm{~km}$ buffer on each side of the road). In GIS maps were also created to analyse the distribution of EWC in Sweden and Västernorrland county as well as the newspaper articles per municipality.

A total of 2,026 newspaper articles were found in the Swedish national media archive (Retriever/Mediearkivet) on crimes against environment and wildlife. These articles were accessed through the National Library of Sweden in Stockholm for the time period 01 January 2000 to 12 May 2012. Keywords used in the search included: 'environmental crime' in combination with (AND) 'pollution', 'leakage', 'chemical, 'release', 'chemicals', 'chemical handling', 'fish', 'animal', 'hunt', 'burning', 'environmental impact.

A total of 1,332 articles remained useful after 694 articles were excluded because they were not related to the subject (e.g. either about law changes, local and national statistics, or international crimes occurring abroad) or were duplicates (e.g. duplicates could come up as the newspaper articles were searched for in several turns using each of the different keywords in combination with environmental crime). The articles refer to: suspected cases of environmental crimes, accused offenders, suspended cases or cases that were tried and did not result in any conviction and cases in trail. It is expected that media coverage would therefore overestimate the total number of offences since some of these cases will turn out to not involve an offence. Table 1 illustrates an attempt to classify EWC using police records and newspaper articles.

The Swedish Homeowners Association (Villaägarnas Riksförbund) performed a survey between February and April 2012 to investigate the price of waste collection. The survey was sent out to all 290 municipalities in Sweden, of which 43 did not reply. Included in the survey were questions on how garbage is collected and what services are included in the price. The prices of garbage collection range from SEK 900 to SEK 3500 a year, with an average price of SEK 2000 a year. Municipalities with the highest price were found in the middle of Sweden, including Dalarna and Södermanland counties. The survey data were also imported into the GIS-database.

Graphs of trends of EWCs and media coverage were created using Microsoft Excel, while correlation analyses were performed in SPSS to analyse the relation between crime and socio-economic variables retrieved from SCB (Statistics Sweden). Note, however, that virtually any spreadsheet software and/or statistical package with similar functions can be used here. To see if any socio-economic variables could better explain why some areas have 
increased EWC records than others, a non-parametric Mann-Whitney U test was applied since some of the variables were skewed. The Mann-Whitney U test has the advantage of being able to assess the relationship between a dependent continuous variable and an independent two-level variable (re-categorized variable 0 and 1, for low and high counts respectively) under no specific distribution of the variables. The test examined if the mean ranks of the two groups were significantly different from each other and thereby showed if either of the groups had a stronger relationship with the independent variable (McKnight \& Najab, 2010).

Table 1: Classification of EWC Using Police Records and Newspaper Articles

\begin{tabular}{|c|c|c|}
\hline & Police & Media \\
\hline Serious EWCs & $\begin{array}{l}\text { Intentional actions that cause } \\
\text { serious environmental damage by } \\
\text { pollution of air, water, soil or } \\
\text { subsoil; storage or disposal of } \\
\text { waste or similar substances. }\end{array}$ & $\begin{array}{l}\text { Intentional damage against air or } \\
\text { soil, water pollution. }\end{array}$ \\
\hline Chemicals & $\begin{array}{l}\text { Unlawful handling of chemicals, } \\
\text { disrupting control and disregarding } \\
\text { regulations and permits of use. }\end{array}$ & $\begin{array}{l}\text { Chemical handling, chemical } \\
\text { leakage, chemical use, etc. }\end{array}$ \\
\hline Nature and wildlife & $\begin{array}{l}\text { Crimes against the protection of } \\
\text { nature, animal abuse and illegal } \\
\text { animal possession as well as } \\
\text { disregarding protected species. }\end{array}$ & $\begin{array}{l}\text { Crimes against hunting, fishing, } \\
\text { animals. Animal abuse and } \\
\text { destruction of nature. }\end{array}$ \\
\hline $\begin{array}{l}\text { Minor and other } \\
\text { EWCs }\end{array}$ & $\begin{array}{l}\text { Others classified as EWC, } \\
\text { dumping, illegal waste } \\
\text { transportation. }\end{array}$ & $\begin{array}{l}\text { Burning materials, dumping waste } \\
\text { or hazardous materials, unlawful } \\
\text { activities, unintentional leakage. }\end{array}$ \\
\hline
\end{tabular}

\section{Trends and the Nature of Crime against the Environment and Wildlife}

Each year there are about 5,000 EWCs reported to the police in Sweden and around 130 cases are registered in the seven rural municipalities of Västernorrland. More important than the actual levels of EWC is perhaps its temporal trend in the last ten years.

EWCs have increasingly reached the media in the last ten years in Sweden with a 330 percent increase between 2000 and 2011. Not surprisingly, the same upward trend is found in police records. Västernorrland county is no different, where there has been an increase both in police records of EWCs (85 percent) and newspaper articles dealing with EWC (300 percent), particularly after 2007 (Figure 2b). This may reflect a real increase in these crimes, as more offences of this type have reached the police statistics. It may also reflect a greater willingness to report such crimes due to improved environmental awareness from increased media coverage of EWCs. For instance, since February 2007 the European Union (EU) applied an EU-wide policy directing its member states to implement minimum legal sanctions 
for environmental crimes, possibly increasing the number of cases reaching court. In Sweden, the municipalities and county councils have an obligation to report an infraction against nature as a crime, for instance during a control check. If these authorities have been more active or they have been targeting certain areas, this could also have influenced the levels and patterns of EWC as well as the media coverage.

Although EWC police records are problematic and a comparison with newspaper articles cannot be fully performed for certain types of EWCs (e.g. Serious EWCs), the two data sources do follow similar trends (Figure 2 and Table 2). When examined by type of crime and municipality, a weak but a positive correlation is found between these data sources. For instance, police records for Serious EWCs are positively correlated with the levels of media attention of air and soil pollution. There is also a significant correlation between Minor EWC records and Minor EWC articles (Table 2).

In general agreement with the first hypothesis, serious EWCs is the category that increased the most in the police records since 2000, both in Västernorrland county and in all of Sweden, certainly because the criminal justice system has been stricter in judging EWC cases in the past decade. Serious environmental crimes may lead to harsh penalties since they cause serious environmental damage by pollution of air, water, soil or subsoil; storage or disposal of waste or similar substances. The type of penalty may also become harsher than before because cases are influenced by media coverage, as we suggest in the fourth hypothesis, but the evidence for this is still patchy. Although official police statistics of serious EWCs cannot be broken down by type (pollution of air, water, soil), newspaper articles show a larger proportion and increase of water pollution cases in relation to soil and air pollution cases.

In Sweden, newspaper articles dealing with water pollution are normally related to oil spills from ships at harbours or factories close to bodies of water (rivers, lakes), as well as conscious dumping of materials, such as oil or other chemicals. A small number of articles refer to the case of oil spills by accident on the road, dumping in urban sewage systems, or leakage due to stealing oil at petrol stations. There were 538 articles in total, but some could be also classified as soil pollution or natural destruction and negatively affecting wildlife (e.g. water pollution leads to killing fish or animals living close to the body of water). Articles on soil pollution are related to soil being polluted by leakage of chemicals or biohazardous material. Also, cases of stored or dumped materials resulting in ground leakage are often related to mining companies. Typical headlines of these crimes include: "Ten thousand cubic meters of liquid fertiliser leaked into the water", "Municipal company X accused of environmentally harmful water pollution" and "Prosecuted for contaminated soil".

Littering and other minor EWCs compose the second largest share in the police statistics and media coverage; more in Sweden overall than in the municipalities of Västernorrland county. Common headlines hitting the newspapers are, for instance; "A large amount of garbage was dumped in the woods" or "Burned furniture became environmental crime". This category is highly dominated by disposal of garbage in forests and on the outskirts of the main urban areas; they tend to be registered close to roads too. 


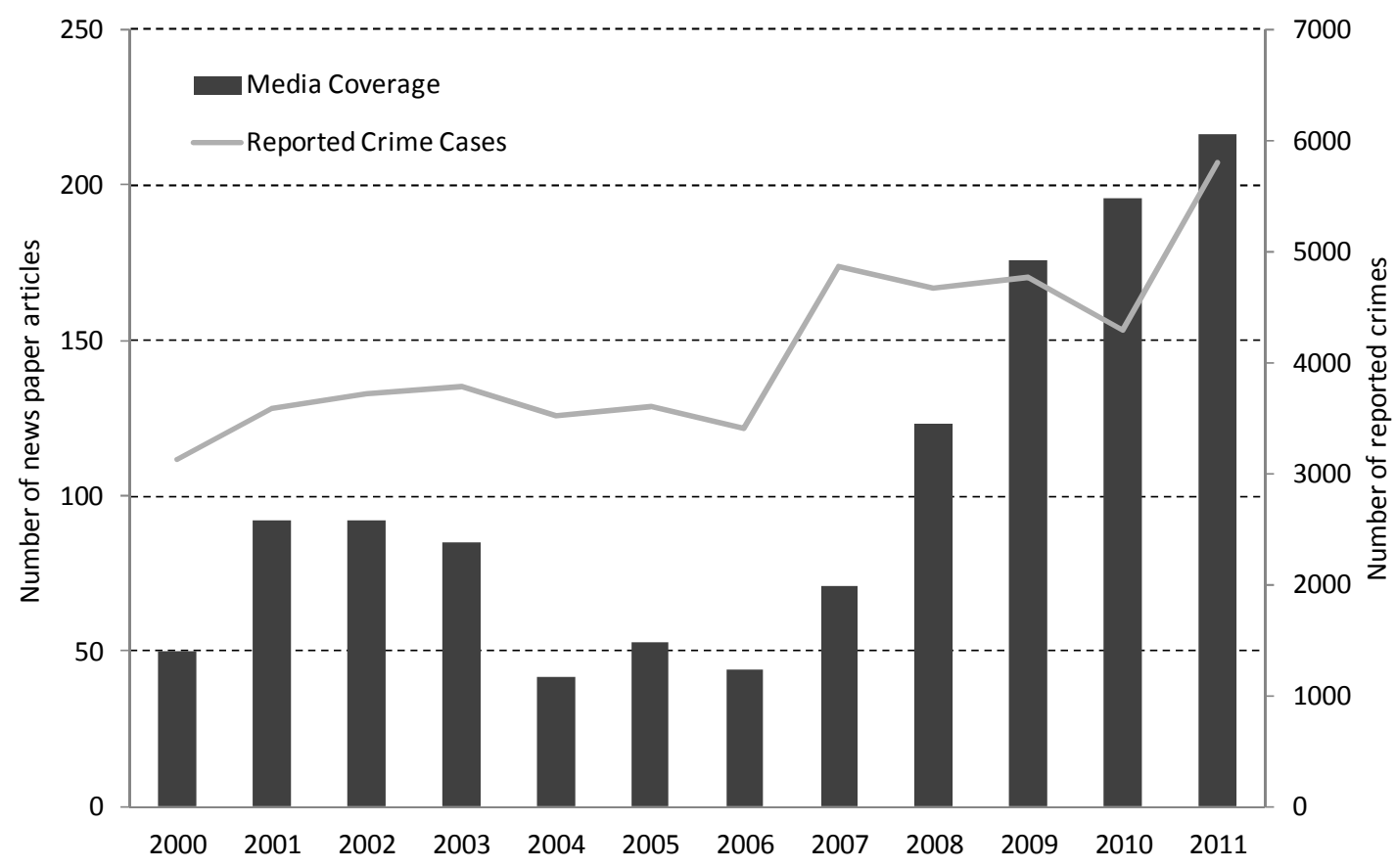

(a)

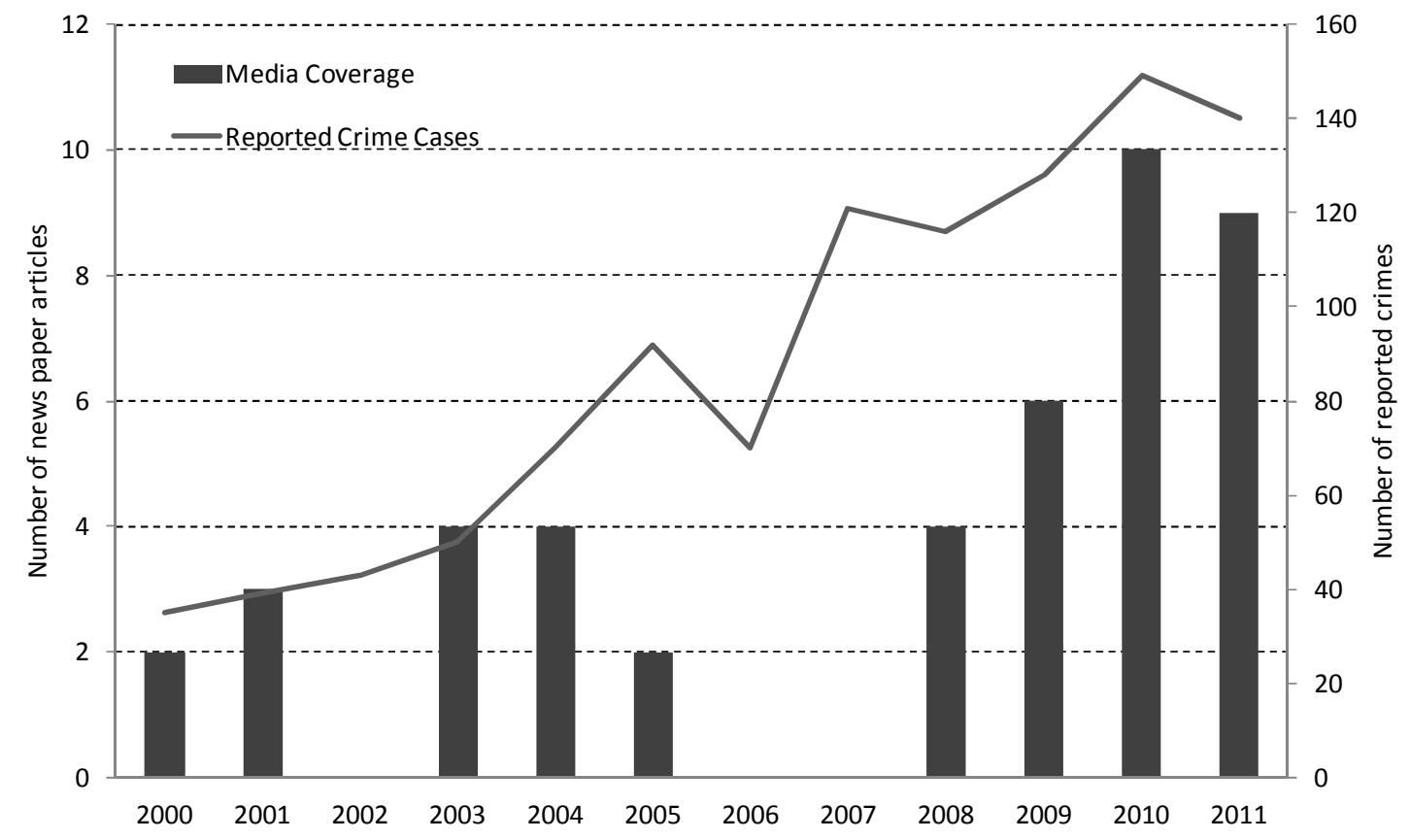

(b)

Figure 2: Environmental and Wildlife Crimes in Sweden and Västernorrland County, According to Police Records and Newspaper Articles (counts between 2000 and 2011) 
Table 2: EWC Police Records and Newspaper Articles by Municipality, 2000-2011

\begin{tabular}{|c|c|c|c|c|c|c|c|}
\hline & $\begin{array}{l}\text { Media } \\
\text { Total }\end{array}$ & $\begin{array}{c}\text { Media } \\
\text { Air }\end{array}$ & $\begin{array}{c}\text { Media } \\
\text { Soil }\end{array}$ & $\begin{array}{l}\text { Media } \\
\text { Water }\end{array}$ & $\begin{array}{l}\text { Media } \\
\text { Minor }\end{array}$ & $\begin{array}{l}\text { Media } \\
\text { Nature }\end{array}$ & $\begin{array}{c}\text { Media } \\
\text { Chemicals }\end{array}$ \\
\hline Police Total & $.330^{* * * *}$ & $.172^{* * * *}$ & $.262^{* * * * *}$ & $.213^{* * *}$ & $.163^{* * * *}$ & $.160 * * *$ & $.247^{* * * *}$ \\
\hline Police Serious & $.328^{* * *}$ & $.130 * *$ & $.260 * * *$ & $.226^{* * *}$ & $.193^{* * *}$ & $.103 *$ & $.238^{* * * *}$ \\
\hline Police Minor & $.234 * * *$ & $.236^{* * *}$ & $.178^{* * *}$ & $.139 * *$ & $.119^{* *}$ & .075 & $.245^{* * * *}$ \\
\hline Police Nature & $.340 * * *$ & .096 & $.246^{* * * *}$ & $.252^{* * *}$ & $.181 * * *$ & $.177^{* * *}$ & $.154^{* * * *}$ \\
\hline Police Chemical & $.397^{* * *}$ & $.149 * *$ & $.304^{* * *}$ & $.265^{* * *}$ & $.186^{* * * *}$ & $.223^{* * * *}$ & $.278^{* * * *}$ \\
\hline
\end{tabular}

No significant correlation was found between high fees for garbage collection and high levels of waste dumpage either for the whole of Sweden or for the rural municipalities (Table $3)$. The lack of correlation might be related to the fact that the survey covers only owned homes (not rental housing) and that a large number of waste dumpages are composed of old cars or appliances and not domestic waste, which is the focus of the homeowner association survey. However, a bit more than one-third of rural municipalities show high levels of waste dumping (including serious cases) and expensive garbage fees. They are in the south and west-coast of the Skandia region and on the east coast close to Stockholm, with some located in central Sweden. As expected, those municipalities that show low garbage collection fees and low waste dumpage are often in smaller Southern rural municipalities, with short commuting distances between them. However, though small municipalities in Northern Sweden tend to be characterised by high waste collection fees, this does not seem to influence levels of waste dumpage. Interestingly, coastal municipalities, especially those who receive many summer tourists, tend to show high levels of waste dumpage despite having low garbage collection fees. All things considered, the second hypothesis is not confirmed.

Table 3- Swedish Municipalities Per Price of Waste Collection and Garbage Dumps

\begin{tabular}{|c|c|c|c|c|c|}
\hline \multirow{3}{*}{ Price of waste collection (SEK) } & \multicolumn{4}{|c|}{ Number of garbage dump } & \multirow[b]{3}{*}{ Total } \\
\hline & & reco & rds & & \\
\hline & $0-5$ & $5-10$ & $10-30$ & $\begin{array}{c}\text { above } \\
30\end{array}$ & \\
\hline $0-1000$ & 1 & 1 & 0 & 0 & 2 \\
\hline $1000-1500$ & 22 & 7 & 3 & 0 & 33 \\
\hline $1500-2000$ & 58 & 23 & 12 & 3 & 96 \\
\hline $2000-2500$ & 55 & 17 & 15 & 0 & 87 \\
\hline above 2500 & 22 & 4 & 1 & 0 & 27 \\
\hline Total & 158 & 52 & 31 & 3 & 245 \\
\hline
\end{tabular}

Data source: Police records and homeowner association, 2011. 
The increase of vehicle dumping in nearby forests is said to be associated with eliminating the government incentive for car owners to leave their old vehicles in the junkyard; which costs about SEK 1700. Instead, many vehicles end up in the woods or even out on the street. For instance, in Sollefteå municipality alone, the police take care of 30 to 40 cars a year according to the local newspaper (Sundin, 2011). The fact that the municipality removes the car does not mean the owner avoids liability. They look for the car owner either by the license plate or the vehicle identification number, when it is visible. The owner is informed about the car and is invited to collect it, which rarely happens. The taxpayers currently cover the cost for vehicle dismantlement and the local authorities have to spend resources to administer the process.

In the police records, the category waste dumpage and other minor crimes included burning of materials and dumping of materials (like batteries), waste, as well as old cars. Important to note is that this category may include a few cases of altering landscape without (full) permission or general damage to nature by, for instance, driving through a nature reserve or using it for sports activities that are not included in the category destruction of nature.

Destruction of nature and crimes against wildlife is a special category in its own right as it encompasses about 10 percent of all EWCs in Sweden (with a bit less in Västernorrland) and has shown a constant trend. Wildlife crimes are hard to quantify, not least because accurate figures do not exist on domestic and wildlife populations and, in many instances, the crime has no human witnesses or victims (Anderson, 1997; Marshal \& Johnson, 2005). Crimes against wildlife that reach the newspapers deal often with illegal hunting and fishing, killing of protected animals or breaking animal rights laws in general. Acts of animal cruelty, such as animal starvation, are not rare. Common headlines of these crimes are; "Major damage to protected natural area" or "Hundreds of protected birds shot without permission".

In half of those newspaper articles that included a potential suspect of committing EWC, the suspects were indicated to be companies located in the area. These companies vary in nature and size, but mining companies, power plants, chemical industries, construction companies, water treatment plants, fish farmers and chain mill factories are commonly mentioned suspects of EWC. Farmers also cover a smaller but significant portion of the articles' potential offenders in cases of water contamination, commercial fishing and destruction of nature. A large share of EWC articles does not indicate a suspect or an offender (41 percent). Companies and their activities were indicated as suspects in 48 percent of the newspaper articles, while 11 percent of indicated suspects were individuals of which most were connected to minor EWCs.

Unlawful handling of chemicals has had a 30 percent decrease over all in Sweden, but a slight increase in Västernorrland county according to police records between 2000 and 2011. These crimes also include a person who intentionally or recklessly handles a chemical, biotechnical organism or article containing or treated with a chemical product without taking the required protective measures, product or precautions, which threatens to cause harm to humans or the environment. "Farmer sentenced for environmental crimes after using banned 
spray" is a typical headline that fits these crimes. These offences also involve starting or carrying on business without consent or approval, without having made a notification, after a complaint initiates an activity or action, or without following a prescribed period, all as required by the authorities.

\section{The Geography of Crime against the Environment and Wildlife}

In order to assess the second hypothesis, EWC records were linked to municipalities' characteristics. As expected, EWCs are not spread evenly among municipalities. Some parts of the country report more EWCs than others and different types of EWC differ from place to place within municipalities. Although 90 percent of recorded crimes took place outside the largest Swedish urban areas, a large share of those was registered in municipalities classified as Accessible Rural.

The recorded EWCs are concentrated in the southern urban triangle of MalmöGothenburg-Stockholm and a few Accessible Rural municipalities in the north of Sweden (Figure 3a). Other smaller and weaker concentrations are found in Accessible Rural municipalities located close to these hot spots and the larger rural municipalities in the north. The EWC concentrations seem to follow patterns similar to those found for property and violent crimes (see, e.g., Ceccato \& Dolmen, 2011).

Media coverage of EWC during the same time period (Figure 3b) shows a pattern similar to, but not exactly like, those found for police recorded offences. Major cases stand out as 'hot spots', like the 'Östersund contamination' and 'Båstad tunnel construction', which were related to water contamination. The first case was detected in Midwest Sweden in the municipality of Östersund in December 2010. The leakage attracted the attention of the national media (43 articles) in a very short period of time since the quality of the water was affected, causing sickness in part of the population living close by. The second case was in the south of Sweden, close to Båstad municipality, and was about a construction of a railway tunnel by two construction companies. Several articles have been published in different newspapers over the past ten years on the pollution of a local river, but also on other types of environmental damages caused near the tunnel construction. The most important charge was related to the toxic waste that was left in a natural reserve and that later leaked into a river and contaminated the water.

There is an interesting concentration of cases along the west coast, both according to police records and media (Figure 3 a and b). These municipalities are Accessible Rural areas, even including some bigger cities, and all have some type of fishing industry and/or harbour activities. The major fishing industries in Sweden are in fact located along this west coast area. Indeed, most of the EWC records are related to water pollution or crimes like chemical usage and dumping, both which are related to one another as well as to the fishing industry and harbour activities.

Also the larger rural municipalities with medium high records show their fair share of media coverage, including, for instance, the 'farming / chemical incident' in Gotland in 2005. Umeå and Luleå, medium to large cities in the north of Sweden, also prove to have a 
concentration of EWC. Umeå peaks as a hotspot for both police and media records (Figure 3). The high rate of EWC relates mainly to chemical usage and soil pollution. Umeå also attracted much media attention for destruction of nature and wildlife crime cases. Both municipalities have mining industries and crimes such as oil spills in the harbour of Umeå are commonly recorded both by the police and newspapers.

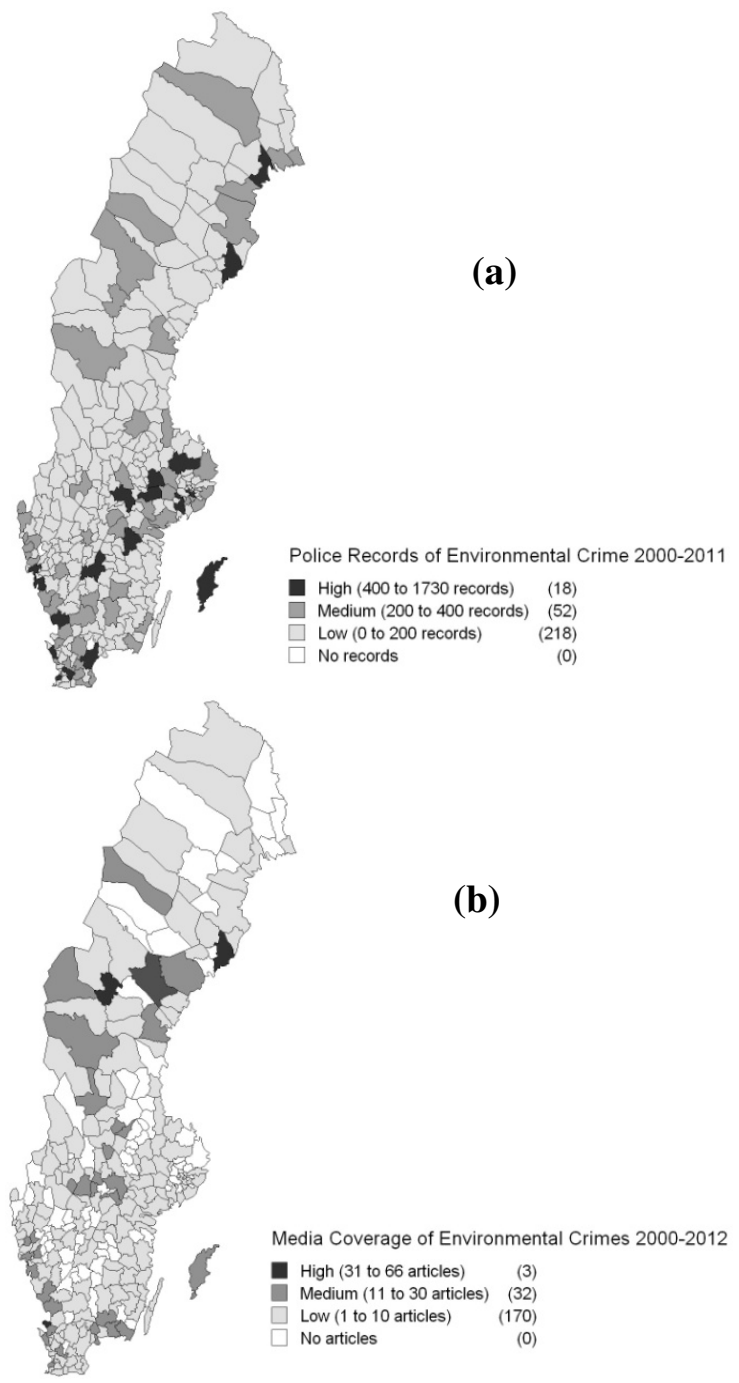

Figure 3: Environmental and Wildlife Crimes Recorded by (a) the Police and (b) Newspapers

Different types of EWCs show different geographies. Serious EWCs are often found in Accessible Rural municipalities within the urban triangle of Malmö-Gothenburg-Stockholm and in larger municipalities in the north, while minor EWCs are recorded in smaller rural municipalities, mainly in the central country and northern areas (Figure 4). This serious-tominor EWC geographical pattern is also captured, to some extent, by the printed media. Media coverage of wildlife crimes occurs only in rural areas, which is understandable considering the type of crime, the greater possibility for hunting and accessing nature, and local public interest in their immediate, natural surroundings. 
EWC records of unlawful handling of chemicals present a concentrated pattern in rural areas (Figure 4) spread out over the country that often include a medium-size city, which indicates some relation to factories and/or industries working with chemicals. Newspaper articles show a similar focus, but for air pollution; media coverage is extremely concentrated to four Accessible Rural municipalities, three of which have an energy production plant and/or paper mill, and the fourth which has a local shooting club $^{5}$. It is difficult to speculate why certain types of EWCs attract more media attention than others (e.g. air pollution instead of unlawful handling of chemicals). In this case, it may be that air pollution is more of a visible occurrence that affects the outside world, relative to a chemical accident that takes place inside a factory.

UA (112)

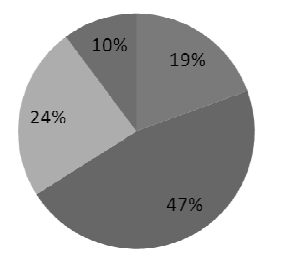

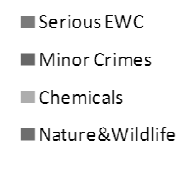

AR (156)
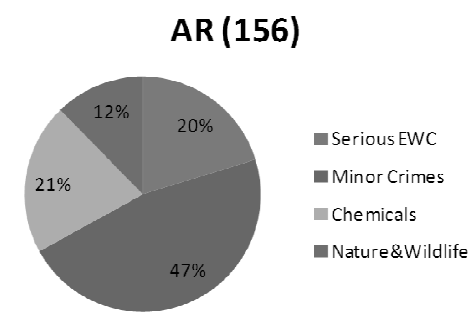

$\operatorname{RR}(22)$

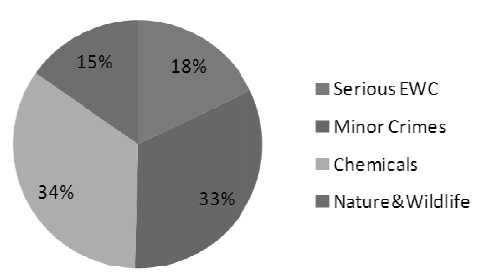

Figure 4: Shares of EWCs in UA - Urban Areas, AR - Accessible Rural and RR - Remote Rural in Sweden, police 2000-2011.

Urban areas see a more varied relation between numbers of EWCs and media articles; the media does not always reflect EWC cases in urban municipalities. There are many possible reasons behind this diverging pattern. Urban areas have relatively lower numbers of EWCs per capita than rural areas, partially because many 'risky industries' are located in more remote locations. Urban areas are also more prone to violent and property crimes than environmental hazards, which more often attracts media attention (Burns 2009; Jarell 2009; Marsh, 1991). Recorded EWCs in urban areas are often related to crimes of dumping and unconscious actions; media coverage shows this as most articles in cities are about Minor EWCs, such as garbage dumping or minor oil spill accidents in harbours.

Is there any particular characteristic common to municipalities with high levels of EWCs? The results from a non-parametric Mann-Whitney U test for all municipalities show that, despite the fact that EWC tends to be rural, municipalities with larger populations tend to have more recorded cases of EWCs and more media attention $(\mathrm{p}=0.01)$. Similar results were obtained when only testing rural municipalities. There is no significant relationship between the size of municipalities (area) and the number of reports and media articles. Only police records of littering and dumping were found to be significantly higher $(\mathrm{p}=0.03)$ in geographically larger municipalities. Findings also indicate that levels of EWC police records by municipality are not affected by unemployment, but that media coverage is $(p=0.05)$; higher level of EWC Media records in areas with high unemployment. Although premature, these findings call for new analysis looking into economic structures, population characteristics and EWC levels in rural Sweden. 


\section{EWC in the County of Västernorrland}

In order to test the third hypothesis of a possible relation between people's routine activity and the detection of EWC records, a case study in the County of Västernorrland was carried out. The detection of EWCs is dependent on what people see in their patterns of daily routine activity. EWC in isolated and remote areas go largely under-detected. Only one-third of EWC cases were recorded within the boundaries of the main urban areas in the county of Västernorrland between 2005 and 2008 (Härnosand, Örnsköldsvik and Sundsvall). The detection of these crimes is dependent on the accessibility of the area via roads, rivers or an urbanised area. For instance, in Västernorrland county, 75 percent of police-recorded environmental and wildlife offences were located within 2 kilometres of roads (indicated by stars in Figure 5a). Garbage dumping is particularly noticeable due its visibility from roads and in the outskirts of urban areas (indicated by triangles in Figure 5a). According to BR (2006), it is often the general public or individual citizens who detect crimes that are visible in nature, such as garbage dumping, old vehicles, waste found in nature or oil spills in water areas. People's routine activity and space awareness of their environments are therefore important for EWC detection in rural areas. This finding, along with the previous finding that there are more occurrences of EWCs in the larger, rural municipalities, lends support to the third hypothesis. Recorded cases depend on detection, and detection is based on reports of what citizens witness as they go about their daily activities.

In Västernorrland county, the media covered fewer than 50 articles on EWC in the last ten years, of which three-fourths focused on Serious EWC and the other fourth on garbage dumping and other minor environmental crimes. The majority of the media coverage is about water and soil pollution as well as destruction of nature and wildlife crime, representing the more easily visible crimes.

Most of the articles were published in local and regional newspapers, while only a few cases made it to national, printed media. Among these few was a sensational story in April 2008 about a mysterious find of a couple of dead and buried cows. Also, the case of pollution of the municipal water collection basins in Örnsköldsvik on several occasions and over a lengthy period of time, led to a trial in June 2005, and a final court decision in $2008^{6}$.

In recent years, a fishing farm at Köpmansholmen in Örnsköldsvik has been under local media scrutiny. Several complaints about the industry had been made and it is now trying to find a new location in the area for its expanding business. Public interest in keeping local business and fighting for a clean environment seems to generate a vivid debate in the county's media. Putting focus on these crimes in a small community can have a major influence on public opinion and indeed a few reader columns confirms this. Below, a reader questions the municipality's decision to dump waste in a local lake: 


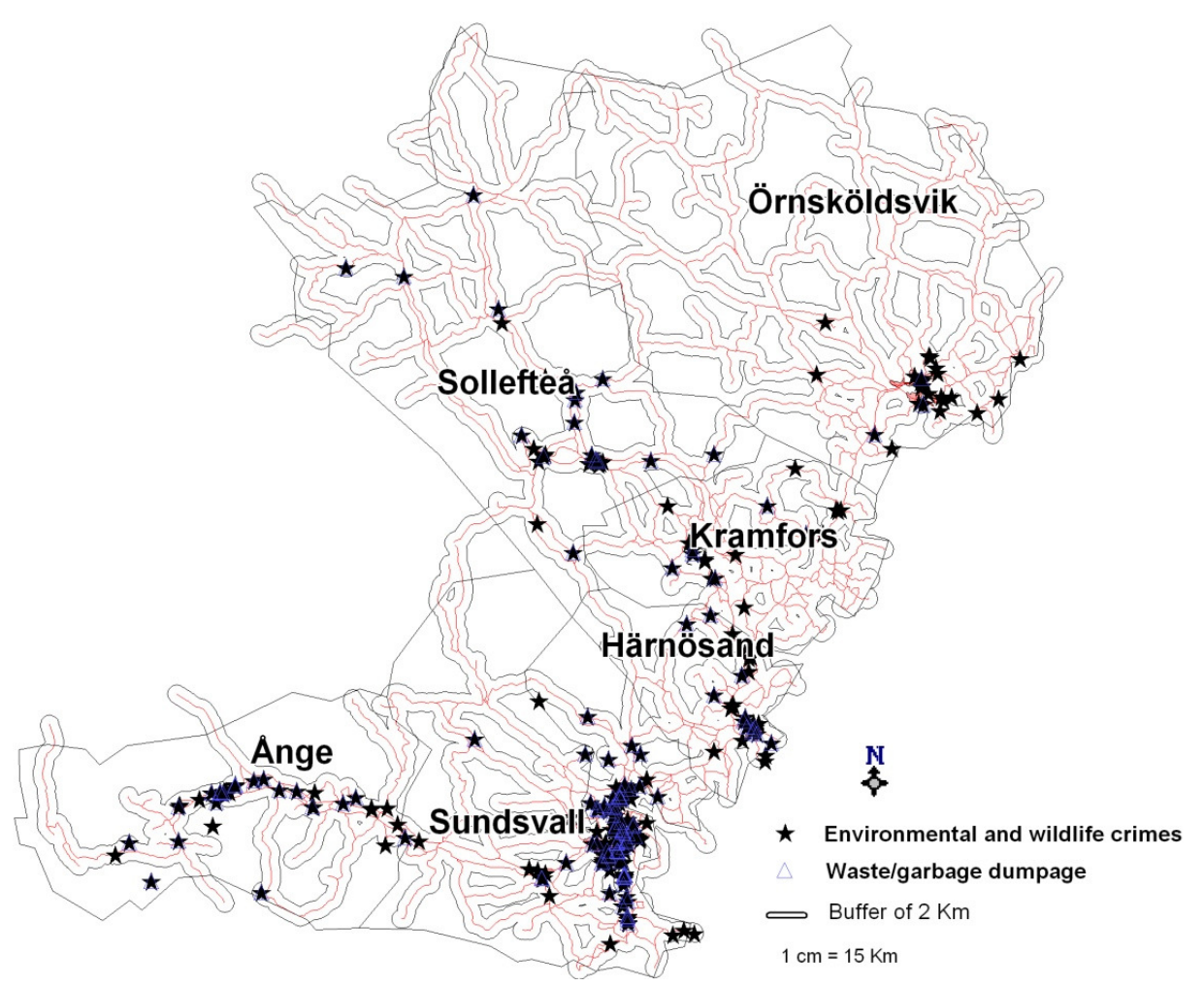

(a)


(b)

Figure 5: Types of Environmental and Wildlife Crimes in Västernorrland County according to (a) Police Records 2005-2008 and (b) Newspaper Articles 2000-2011. 
"How can one release waste water in Hamstasjön? Obviously that is an environmental crime (...) School kids are taught not to dump waste in nature, but what will they think if the municipality directs wastewater into the lake. (...) Wake up and act! Several village residents are protesting against this stupid decision. The environmentally friendly municipality? I doubt it!" (Sundsvalls Tidning, 07 February 2010) ${ }^{7}$

Some EWC cases on the coast of Västernorrland refer to illegal construction and water resources management. According to BRA's report, this is a common problem that causes serious damage to the Swedish coastal ecosystem (BRA, 2006:32-34). However, the role of municipal authorities in the process of approving permits for building along the coast is unknown. Municipalities in Sweden have a monopoly on planning and are, at the same time, the most important authority in detecting EWC.

\section{Conclusions and looking ahead}

This article aimed to provide a better understanding of EWC in the rural, Swedish context. The study used two main data sources: police records and newspaper articles. Findings show an increase in both EWC recorded by the police and by media coverage in the last decade, which is what we suggested in the first hypothesis. Although crimes against environment and wildlife are rural phenomena, EWC's geography varies by EWC crime type. The case study of Västernorrland county provided a glimpse of what can be analyzed in terms of EWC location and people's routine activity, which is important to EWC detection. These findings are promising and can provide insights for EWC control and prevention.

Certain municipalities are more prone to specific EWC types than others. Rural areas are in general more prone to unlawful handling of chemicals and nature and wildlife crimes than urban areas. Contrary to expectations as stated in the second hypothesis, a high price for garbage collection did not result in more illegal garbage dumping. Future research is needed to investigate whether the economic structures of these communities play a role in EWC levels. Equally important is to assess whether socio-economic risk factors of the population affect the occurrence of crimes against nature.

Although crimes against environment and wildlife are rural phenomena, the geographic pattern varies by the type of EWC. The case study of Västernorrland County provided a glimpse of what can be analyzed in terms of EWC location and people's routine activities, which is important to EWC detection. The case study of Västernorrland county neatly aligned with the third hypothesis which proposed that EWC detection patterns follow people's routine activity, awareness of space and the place's natural opportunity for surveillance. EWC records and, in particular, records of dump of garbage dumping and littering can often be found in accessible areas; for example, near roads, but not too close to urban areas, as that may increase the risk of being detected or recognized. Police records also showed that larger municipal areas could mean an increase in cases of dumping. The adoption of electronic surveillance along roads could, for instance, be an alternative to increasing surveillance in areas more targeted by garbage dumping. 
Routine activity principles can be the basis for assessing detection schemes and EWC concentrations. Popular places may see more EWCs, which then can be easily combated by improving surveillance and security of that particular spot. Future research should focus on finding ways to deal with the problem and how to implement such preventive schemes. Moreover, if principles of routine activity are to be used in public campaigns, such dumping spots should be better supervised and may be under indirect social control of the local community.

This study faced some difficulties in analysing the varied dimensions of EWCs: it was found that victims, offenders, and actual harm are often difficult to identify precisely with the data used in this study. Moreover, media does not pick up on minor EWCs, so they remain highly underreported compared to other police records. Nevertheless, both data sources have seen an increase in reports in the last decade, in particular during the last five years, confirming the both the first and fourth hypotheses of increased levels of EWC. Environmental awareness must have played a role in this rise.

This study relates only to what happened within national boundaries. There seems to be a consensus that future research should focus on cross-border trafficking of waste, but also of endangered species of plants and animals, which seem to be a lucrative industry. There is little empirical evidence on this from Sweden or elsewhere in the literature - what exists is still based on tales and anecdotes from newspapers and internet that do not hold up under the scrutiny of a systematic analysis. More research is therefore needed.

The Swedish evidence confirms the fourth hypothesis that more crimes are recorded in places where media has a greater focus on EWC cases. Police records increased when media coverage increased or vice versa. In fact, the focus of media coverage in certain cases has lead to thorough investigations by the police; take as an example the 'Östersund contamination' and the 'Båstad tunnel construction' described in this paper. Municipalities with high media coverage of EWC show medium to high levels of police cases. On the other hand, it can be said that media does not play a large role itself in detecting EWCs, rather it is the municipal environmental authorities and the police that control the information provided to the media. Yet, the media is foremost interested in 'the discovery' and early developments of a crime case, not the investigation and trials, suggesting that media can positively affect detection of EWC and awareness. In some of the analysed cases, printed media has been the "whistle blower" for an EWC, such as pollution, which raises voices and awareness among the public. Nevertheless, much depends on the willingness of the local authorities to proceed and convict suspects. Evidence from this study puts forward the question of whether some cases never reach court because of the pressure local authorities put on those involved in investigating EWC. Future studies should assess whether the interaction between the authorities' investigations and the media affect EWCs outcomes. The issues of social and economic sustainability of rural areas must be assessed in relation to the environmental dimension. Nature should be seen as a means for rural development at the same time that EWC cannot be excused for the sake of "doing business". It is therefore important to take a closer look at the barriers that make difficult the detection of environmental violations as well as the reasons of why violations rarely go to trial. This article makes a contribution to this 
knowledge basis by providing an example of how the use of principles of routine activity can be useful for detection of environmental violations.

\section{Endnotes}

${ }^{1}$ Företagare döms för nedskräpning', Timrå, 24th November 2011, Sundsvall Tidningen, at http://st.nu/medelpad/timra/1.4133546-foretagare-doms-for-nedskrapning.

${ }^{2}$ Daily rates (Dagsböter) is a form of fines which the number of fines depends on the crime and sentence difficulty or penalty and by a person's income. Two people can then be judged for the exact same crime, receive the same number of fines, but different fines because they have different incomes. This differs from monetary fines amounting to a fixed amount. The number of fines is determined by how serious the crime is considered to a low of 30 and a maximum of 150. These fines are common in countries such as Sweden, Finland, Denmark and Germany (Wikipedia, 2013).

${ }^{3} 1 \mathrm{SEK}($ Swedish Krona $)=0.16$ US Dollar; $1 \mathrm{SEK}=0.118485$ EUR.

${ }^{4}$ Swedish words were used for the search as the archive is in Swedish and we are looking at Swedish newspapers. The keywords are, respectively: 'miljöbrott' AND 'förorening', 'läckage', 'kemikali', 'utsläpp', 'kemikalier', 'kemikalihantering', 'fisk', 'djur', 'jakt', 'eldning', 'miljöpåverkan'.

${ }^{5}$ Borlänge Energi and Kvarnsveden Paper Mill, Skoghall's Stora Enso Paper Mill (packaging) and formerly Akzo Nobel Chemicals, Sölvesborg Energi and Paper Mills, Börringekloster's Shooting Society.

${ }^{6}$ http://www.notisum.se/rnp/domar/rh/RH009017.htm

${ }^{7}$ http://st.nu/opinion/ordetfritt/1.1786188-avloppsvatten-gar-ut-i-hamstasjon 


\section{References}

Adler, R.W. \& Lord, C. (1991). Environmental crimes: Raising the stakes. George Washington Law Review, 59, 781-790

Aimer, C. \& Goeschl, T. (2010). Environmental crime and punishment: empirical evidence from the German penal code. Land Economics, 86, 707-726.

Anderson, S. (1997). A study of crime in rural Scotland. Edinburgh: The Scottish Office.

Brantingham, P. \& Brantingham, P. (1984). Patterns in Crime. Macmillan, New York.

BRÅ, Brottsförebyggande rådet (Swedish National Council for Crime Prevention). (2006). 'Är vi bra på miljöbrott? En snabbanalys.' (Are we good at environmental crimes? A quick scan.). Webrapport 2006:5 retrieved from www.bra.se

Burns, R.G. (2009). Environmental crime. In J. Miller (Ed.), 21 st Century criminology: A reference handbook. (pp.481-489). Thousand Oaks: SAGE Publications, Inc.

Burns, R.G. \& Orrick, L. (2002). Assessing newspaper coverage of corporate violence: the dance hall fire in Goteborg, Sweden. Critical Criminology 11, 137-150.

Ceccato, V. \& Dolmen, L. (2011). Crime in rural Sweden. Applied Geography, 31, 119-135

Cohen, L.E. \& Felson, M. (1979). Social Change and Crime Rate Trends: A Routine Activity Approach. American Sociological Review, 44, 588-608

Jarell, M.L. (2007). Environmental crime and media: News coverage of petroleum industry violations. New York: LFB Scholarly Publishing.

Jarell, M.L. (2009). Environmental crime and injustice: media coverage of a landmark Environmental crime case. The Southwest Journal of Criminal Justice, 6, 25-44

Marsh, H.L. (1991). A compartive analysis of crime coverage in newspapers in the United States and other countries from 1960-1989: A review of the literature. Journal of Criminal Justice, 19, 67-79.

Lynch, M.J., Stretesky, P.B. \& Hammond, P. (2000). Media coverage of chemical crimes, Hillsborough County, Florida, 1987-97. The British Journal of Criminology, 40, 112126.

Marshall, B. \& Johnson, S. (2005). Crime in rural areas: A review of the literature for the rural evidence research centre. UCL London - Jill Dando Institute of Security and Crime Science.

Martin, D., Brigham, P., Roderick, P., Barnett, S., \& Diamond, I. (2000). The (mis)representation of rural deprivation. Environment and Planning A, 32, 735-75. 
McKnight, P. E. \& Najab, J. (2010). Mann-Whitney U Test. Corsini Encyclopedia of Psychology. Volume 1.

National Encyclopaedia. (2012). Environment - Sweden - problem, growth, area, farming, power. Accessed via http://www.nationsencyclopedia.com/Europe/SwedenENVIRONMENT.html\#ixzz24SXKiNzc, 18 September 2012.

Pendleton, M.R. (1997). Beyond the threshold: The criminalization of logging. Society and Natural Resources, 10, 181-193.

Regeringskanslietsrättsdatabaser - Government office penal database. (2012). 'Grovt miljöbrott.' Available at Government office penal database, http://www.regeringen.se/. Accessed 24 August 2012.

Sazdovska. M.M. (2009). Elimination of ecological crime as a part of organized crime in the former Yugoslav Republic of Macedonia. The Review of International Affairs, 60, 8091.

SBC (Statistiska centralbyrån). (2011). Online table 'Folkmängd i län 1749-2010' (Population per county 1749-2010). Retrieved 02 August 2012, data created 08 December 2011.

Skinnider, E. (2011). Victims of environmental crime: Mapping the issues. Vancouver: The International Centre for Criminal Law Reform and Criminal Justice Policy.

SOU (Statens Offentliga Utredningar). (2002). Polisverksamhet i förändring. Delbetänkande från polisverksamhetsutredningen, Justitiedepartementet, Statens offentliga utredningar, 70. (Police duties are changing. Interim report from police duty investigations, Ministry of Justice, Swedish Public Investigations).

Sundin, J. (2011). Skrotbilar i naturen (Dump cars in nature). Published in Allehanda (http://allehanda.se/start/solleftea/1.2557754-skrotbilar-i-naturen?m=print, December 2011).

Swedish Environmental Protection Agency. (2011). Right of public access - a unique opportunity. (http://www.naturvardsverket.se/sv/Start/Om-Naturvardsverket/Varapublikationer/ISBN1/8500/978-91-620-8522-3/, retrieved 07 July 2012.

Swedish Homeowners Association. (Villaägarnas Riksförbund) (2012). Avfallsavgifter för småhusägare per kommun 2011-2012.

SNRDA - Swedish National Rural Development Agency. (2005). Sveriges gles- och landsbygder 2005 (Sweden's rural and country sides 2005). Edita Västra Aros, Västerås

Uhlmann, D. M. (2011). After the spills is gone: The Gulf of Mexico, environmental crime, and the criminal law. Michigan Law Review, 109, 1413-1462. 
Environmental and Wildlife Crime in Sweden - Ceccato \& Uittenbogaard

Västernorrlands County Council. (2012). Homepage accessed 03 August 2012-08-03 http://www.lansstyrelsen.se/vasternorrland/Sv/om-lansstyrelsen/omlanet/Pages/default.aspx

Wikipedia. (2013) Dagsbötter. Available at http://sv.wikipedia.org/wiki/Dagsb\%C3\%B6ter, Accessed February, 20, 2013.

White, R. (2003). Environmental issues and the criminological imagination. Theoretical Criminology, 7, 483-506.

White, R. (2008). Crimes against nature: Environmental criminology and ecological justice. Willan Publishing, Oregon, USA 
International Journal of Rural Criminology, Volume 2, Issue 1 (December), 2013

\section{Appendix 1: Data Sources}

\begin{tabular}{|c|c|c|c|c|}
\hline Database & Data & Source & Type & Date \\
\hline External & $\begin{array}{l}\text { Price of garbage } \\
\text { collection per year } \\
\text { (price in SEK) }\end{array}$ & Home Owner Survey 2011 & Text & $\begin{array}{l}2011- \\
2012\end{array}$ \\
\hline Own & $\begin{array}{l}\text { Media coverage } \\
\text { Newspaper articles on } \\
\text { EWC }\end{array}$ & $\begin{array}{l}\text { National Media Archive } \\
\text { (Retriever) }\end{array}$ & Text & $\begin{array}{l}2000- \\
2012\end{array}$ \\
\hline External & $\begin{array}{l}\text { Environmental crime } \\
\text { records } \\
\text { (crime codes: } 8000- \\
\text { 8019, see Appendix 2) }\end{array}$ & $\mathrm{BR} \AA$ & $\begin{array}{l}\text { Database } \\
\text { (Excel sheet) }\end{array}$ & $\begin{array}{l}2000- \\
2011\end{array}$ \\
\hline External & $\begin{array}{l}\text { Environmental crime } \\
\text { records }\end{array}$ & Västernorrlandspolisen & $\begin{array}{l}\text { GIS database } \\
\text { (incl. } \\
\text { coordinated) }\end{array}$ & $\begin{array}{l}2005- \\
2008\end{array}$ \\
\hline External & Swedish municipalities & Lantmäteriet & GIS data & NA \\
\hline External & Land-use data & $\begin{array}{l}\text { Lantmäteriet, GSD-maps } \\
\text { Sverigekartan/Fastighetskartan }\end{array}$ & GIS data & NA \\
\hline External & $\begin{array}{l}\text { Socio-economic data } \\
\text { per municipality }\end{array}$ & SCB & $\begin{array}{l}\text { Database } \\
\text { (Excel sheet) }\end{array}$ & $\begin{array}{l}2000- \\
2010\end{array}$ \\
\hline
\end{tabular}




\section{Appendix 2: EWC Codes}

\begin{tabular}{|c|c|c|c|}
\hline $\begin{array}{l}\text { Swedish } \\
\text { Penal } \\
\text { Code }\end{array}$ & Swedish description & English translation & Crime category \\
\hline 8001 & Grovt miljöbrott & $\begin{array}{l}\text { Serious crimes against } \\
\text { nature (incl. water, soil, and } \\
\text { air pollution) }\end{array}$ & $\begin{array}{l}\text { Serious crimes against } \\
\text { nature }\end{array}$ \\
\hline 8002 & $\begin{array}{l}\text { Brott mot miljöbalken, vållande till } \\
\text { miljöstörning }\end{array}$ & $\begin{array}{l}\text { Inflicting environmental } \\
\text { disturbance }\end{array}$ & $\begin{array}{l}\text { Destruction of nature and } \\
\text { wildlife }\end{array}$ \\
\hline 8003 & $\begin{array}{l}\text { Miljöfarlig kemikaliehantering, } \\
\text { olovlig kemikaliehantering }\end{array}$ & $\begin{array}{l}\text { Unlawful handling of } \\
\text { chemicals }\end{array}$ & $\begin{array}{l}\text { Unlawful handling of } \\
\text { chemicals }\end{array}$ \\
\hline 8004 & $\begin{array}{l}\text { Brott mot miljöbalk, otill miljöverks } \\
\text { gm avsaknad av tillstånd etc. }\end{array}$ & $\begin{array}{l}\text { Unpermitted environmental } \\
\text { works without permission }\end{array}$ & $\begin{array}{l}\text { Unlawful handling of } \\
\text { chemicals }\end{array}$ \\
\hline 8005 & $\begin{array}{l}\text { Brott mot miljöbalk, otill miljöverks } \\
\text { gm bryta mot villkor i tillst etc. }\end{array}$ & $\begin{array}{l}\text { Unpermitted environmental } \\
\text { works by breaking rules of } \\
\text { permission }\end{array}$ & $\begin{array}{l}\text { Unlawful handling of } \\
\text { chemicals }\end{array}$ \\
\hline 8006 & $\begin{array}{l}\text { Brott mot miljöbalken, försvårande av } \\
\text { miljökontroll }\end{array}$ & $\begin{array}{l}\text { Increasing difficulty of } \\
\text { environmental control }\end{array}$ & $\begin{array}{l}\text { Unlawful handling of } \\
\text { chemicals }\end{array}$ \\
\hline 8007 & $\begin{array}{l}\text { Brott mot miljöbalken, bristfällig } \\
\text { miljöinformation }\end{array}$ & $\begin{array}{l}\text { Provision of incomplete } \\
\text { environmental information }\end{array}$ & $\begin{array}{l}\text { Unlawful handling of } \\
\text { chemicals }\end{array}$ \\
\hline 8008 & Brott mot miljöbalken, nedskräpning & Dumping, littering & Minor/petty and others \\
\hline 8009 & $\begin{array}{l}\text { Brott mot miljöbalken, avs naturvård } \\
\text { och artskydd }\end{array}$ & $\begin{array}{l}\text { Crime with regards to nature } \\
\text { conservation and species } \\
\text { protection }\end{array}$ & $\begin{array}{l}\text { Destruction of nature and } \\
\text { wildlife }\end{array}$ \\
\hline 8010 & $\begin{array}{l}\text { Brott mot miljöbalken, avs } \\
\text { miljöskydd och vattenverksamhet }\end{array}$ & $\begin{array}{l}\text { Crime with regards to } \\
\text { environmental protection } \\
\text { and water works }\end{array}$ & $\begin{array}{l}\text { Destruction of nature and } \\
\text { wildlife }\end{array}$ \\
\hline 8011 & $\begin{array}{l}\text { Brott mot miljöbalken, i samband med } \\
\text { kemikaliehantering etc. }\end{array}$ & $\begin{array}{l}\text { Crime with regards to } \\
\text { handling of chemicals }\end{array}$ & $\begin{array}{l}\text { Unlawful handling of } \\
\text { chemicals }\end{array}$ \\
\hline 8012 & $\begin{array}{l}\text { Brott mot miljöbalken, förbud mot } \\
\text { djurhållning m.m. }\end{array}$ & $\begin{array}{l}\text { Crime against prohibition of } \\
\text { animal keeping }\end{array}$ & $\begin{array}{l}\text { Destruction of nature and } \\
\text { wildlife }\end{array}$ \\
\hline 8013 & $\begin{array}{l}\text { Brott mot miljöbalken, obeh befattn } \\
\text { med djur eller växtart etc }\end{array}$ & $\begin{array}{l}\text { Illegal custodianship of } \\
\text { animals or plant species }\end{array}$ & $\begin{array}{l}\text { Destruction of nature and } \\
\text { wildlife }\end{array}$ \\
\hline 8014 & $\begin{array}{l}\text { Brott mot lagen om åtgärder mot } \\
\text { föroreningar från fartyg }\end{array}$ & $\begin{array}{l}\text { Crime with regards to } \\
\text { measures against pollution } \\
\text { from ships }\end{array}$ & $\begin{array}{l}\text { Serious crimes against } \\
\text { nature }\end{array}$ \\
\hline 8015 & $\begin{array}{l}\text { Brott mot områdesskydd, förseelse } \\
\text { mot områdesskydd }\end{array}$ & $\begin{array}{l}\text { Crime and offence against } \\
\text { conservation areas }\end{array}$ & $\begin{array}{l}\text { Destruction of nature and } \\
\text { wildlife }\end{array}$ \\
\hline 8016 & Artskyddsbrott inkl. grovt & $\begin{array}{l}\text { Serious crime against } \\
\text { species protection }\end{array}$ & $\begin{array}{l}\text { Destruction of nature and } \\
\text { wildlife }\end{array}$ \\
\hline 8017 & Övriga brott mot miljöbalken & $\begin{array}{l}\text { Other crimes against } \\
\text { environmental laws }\end{array}$ & Minor/petty and others \\
\hline 8018 & Otillåten nationell avfallstransport & $\begin{array}{l}\text { Unpermitted national waste } \\
\text { transport }\end{array}$ & Minor/petty and others \\
\hline 8019 & $\begin{array}{l}\text { Otillåten gränsöverskridande (inom, } \\
\text { till och från EU) avfallstransport }\end{array}$ & $\begin{array}{l}\text { Unpermitted international } \\
\text { waste transportation (within } \\
\text { EU) }\end{array}$ & Minor/petty and others \\
\hline
\end{tabular}

Source: BRÅ, 2012. 